\title{
Paleocene and
}

\section{Lower Eocene Units in}

the Southern Part of the

Piceance Creek Basin

\section{Colorado}

By JOHN R. DONNELL

C ON TR I B U T I ON S TO STRA TIGRAPHY

GEOLOGICAL SURVEY BULLETIN 1274-M

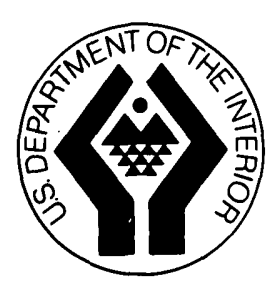


UNITED STATES DEPARTMENT OF THE INTERIOR

WALTER J. HIGKEL, Secretary

\author{
GEOLOGICAL - SURVEY
}

William T. Pecora, Director

U.S. GOVERNMENT PRINTING OFFICE, WASHINGTON : 1969

For sale by the Superintendent of Documents, U.S. Government Printing Office Washington, D.C. 20402 - Price 20 cents 


\section{CONTENTS}

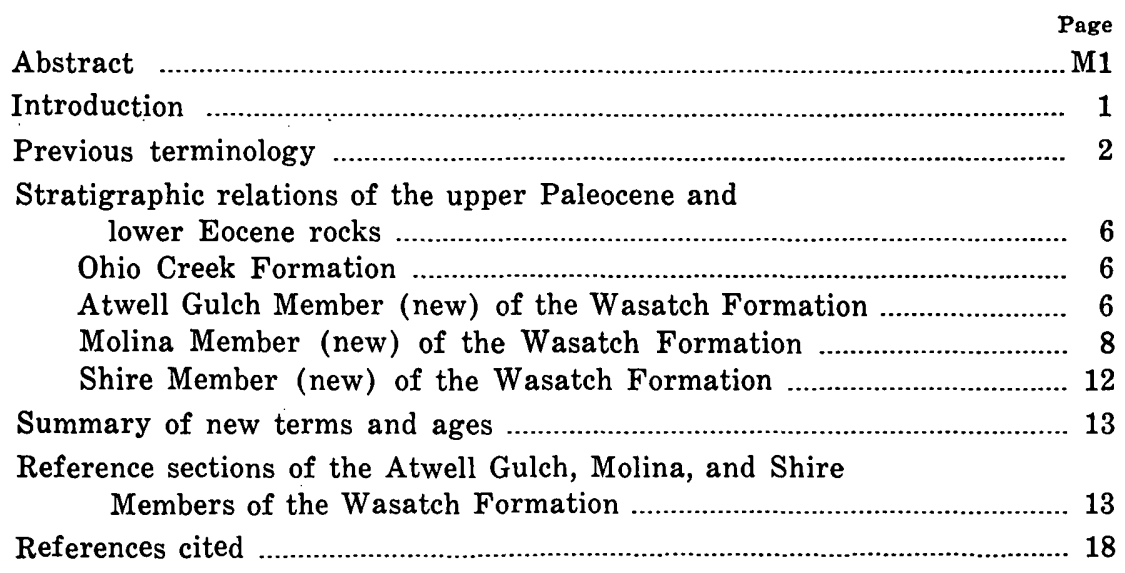

\section{ILLUSTRATIONS}

Figure 1. Map of the Piceance Creek basin, northwestern Colorado

2. Map of the area along Plateau Creek and along the Colorado River between Rifle and DeBeque Canyon

3. Generalized stratigraphic relations of the Wasatch and adjacent formations in the southern part of the Piceance Creek basin

4. Molina Member of the Wasatch Formation, capping hill east of DeBeque, underlain by incompletely exposed Atwell Gulch Member

5. Steeply dipping rocks at Rifle Gap 9

6. Vertebrate quarry in Atwell Gulch Member 10

\section{TABLE}

TABLE 1. Cretaceous and Tertiary names used in geologic reports on the Piceance Creek basin 


\title{
PALEOCENE AND LOWER EOCENE UNITS IN THE SOUTHERN PART OF THE PICEANCE CREEK BASIN, COLORADO
}

\author{
By JOHN R. DONNELL
}

\begin{abstract}
The age relations of the Wasatch Formation in northwestern Colorado have long been controversial. It is the purpose of this paper to summarize available paleontological information on the Wasatch Formation, to describe the general stratigraphic relations, and to designate formal names for informal units initially described by Donnell in 1961.

Sedimentary rocks in the interval between the Ohio Creek Formation and the Green River Formation are assigned to the Wasatch Formation of Paleocene and Eocene age. In an area of several hundred square miles in the vicinity of DeBeque, Grand Valley, Mesa, and Collbran, Colo., the Wasatch may be separated into three members. The upper and lower members, herein named Shire and Atwell Gulch, are dominantly variegated claystones. The intervening Molina Member consists principally of thick brown ledge-forming massive sandstones with thin interbeds of variegated claystone. The lower 200 feet of the Atwell Gulch Member contains Paleocene plant and vertebrate fossils. No fossils have been reported from the Molina or the upper part of the Atwell Gulch Member; however, the Shire Member contains middle early and late early Eocene vertebrate fossils. Stratigraphic equivalents of these three members crop out along the Grand Hogback between Rifle and Meeker, Colo.
\end{abstract}

\section{INTRODUCTION}

The Ohio Creek Formation, a Paleocene unit characterized by conglomeratic sandstones containing mostly pebbles of chert and quartzite derived primarily from Paleozoic sediments, marks the boundary between the Cretaceous and Tertiary Systems throughout most of the Piceance Creek basin. Immediately overlying the Ohio Creek Formation, at some places in the basin, is a series of drab brown and gray shales and sandstones with several thin nonpersistent interbeds of lignite and carbonaceous shale. These beds are herein named the Atwell Gulch Member. Elsewhere, this sequence of beds intertongues with varicolored claystones, silt- 
stones, and sandstones, generally mapped as part of the Wasatch Formation. Late Paleocene vertebrate and plant remains have been found near the base of the unit near DeBeque and Molina and in the area between these places (figs. 1, 2).

Overlying this lowest sequence of beds in an area of several hundred square miles surrounding DeBeque is a unit herein named the Molina Member, consisting mainly of sandstone with thin interbeds of varicolored claystones and siltstones. A similar, but not as well defined, unit is at approximately the same stratigraphic horizon along the eastern margin of the Piceance Creek basin between the Colorado and White Rivers.

Varicolored claystones and siltstones, mainly purple, lavender, and red, and minor amounts of lenticular brown sandstone lie between the dominantly sandstone sequence and the basal unit of the Green River Formation, the Douglas Creek Member, in much of the Piceance Creek basin. This unit is herein named the Shire Member.

\section{PREVIOUS TERMINOLOGY}

Gale (1910, p. 81 ), although recognizing along the Grand Hogback a sequence of rocks of possible equivalence to the Fort Union Formation, stated, "As shown here and also as formerly mapped by the Hayden Survey, all the beds overlying the coal-bearing or Mesaverde formation were included in the Wasatch up to the sandstones that form the basal portion of the next succeeding or Green River formation." (See table 1.)

Along the southern margin of the Piceance Creek basin (in the West Elk Mountains and on Grand Mesa) Lee (1912) regarded the Wasatch ("Ruby") Formation as the rock unit lying between the Ohio Creek Conglomerate and the Green River Formation.

In the Book Cliffs area north of Grand Junction, Erdmann (1934) regarded as belonging to the Wasatch Formation those sedimentary rocks above his Tertiary(?) sandstone (which he tentatively correlated with the Ohio Creek Conglomerate to the south) and below the Green River Formation.

Patterson (1933) initially described Paleocene mammals from what he termed the "lower levels of the Ruby formation" in the vicinity of the Grand (Colorado) River. Later, Patterson (1934, 1936, 1939) described additional Paleocene collections from the lower 200 feet of what he initially termed "Ruby formation." Wood and others (1941) called the beds between the Hunter Canyon Formation (of the Mesaverde Group) and the Green River Formation, DeBeque Formation.

Donnell (1961a) mapped all beds between the Mesaverde Formation and the Green River Formation with the Wasatch Forma- 


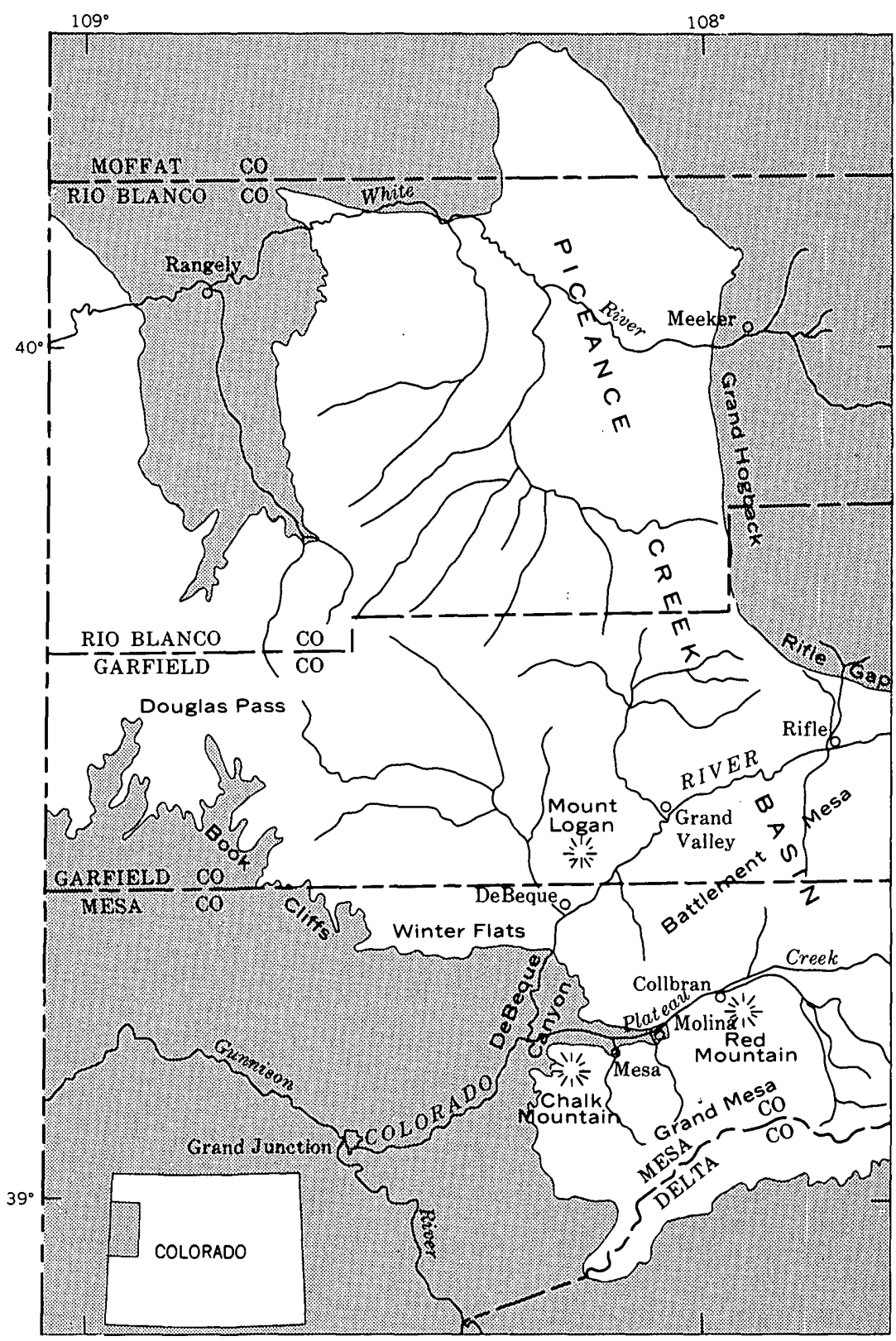

25 MILES

Figure 1.-Piceance Creek basin, northwestern Colorado. Surface rocks are Tertiary in the unpatterned area and pre-Tertiary in the shaded area. 


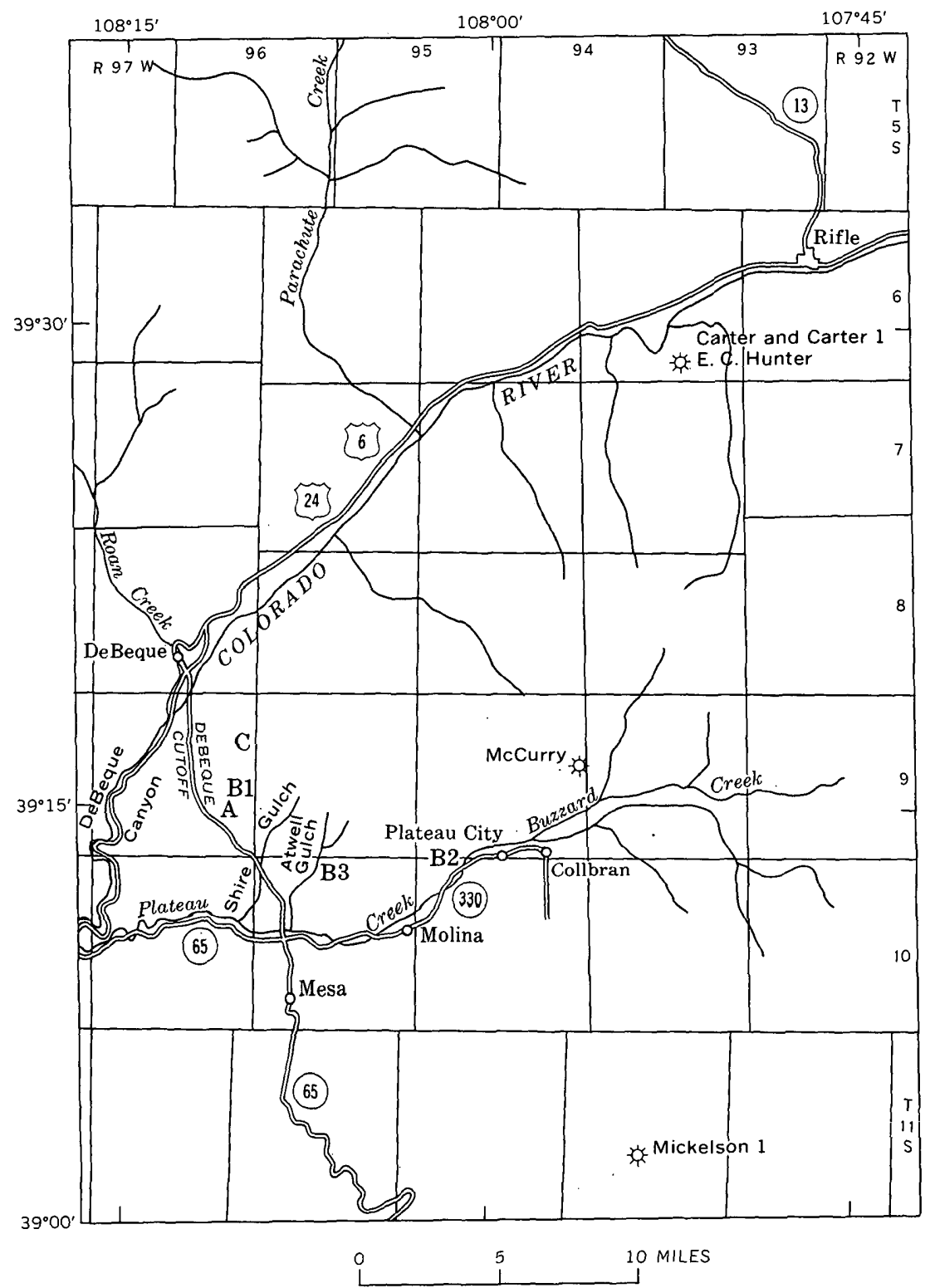

FigURE 2.-Area along Plateau Creek and along the Colorado River between Rifle and DeBeque Canyon. A, reference section for Atwell Gulch Member; B1, B2, B3, reference sections, Molina Member; C, reference section, Shire Member.

tion, and in the report (1961a, p. 844-845) mentioned an unnamed unit of Paleocene age that is the approximate equivalent of the 
PICEANCE CREEK BASIN, COLORADO

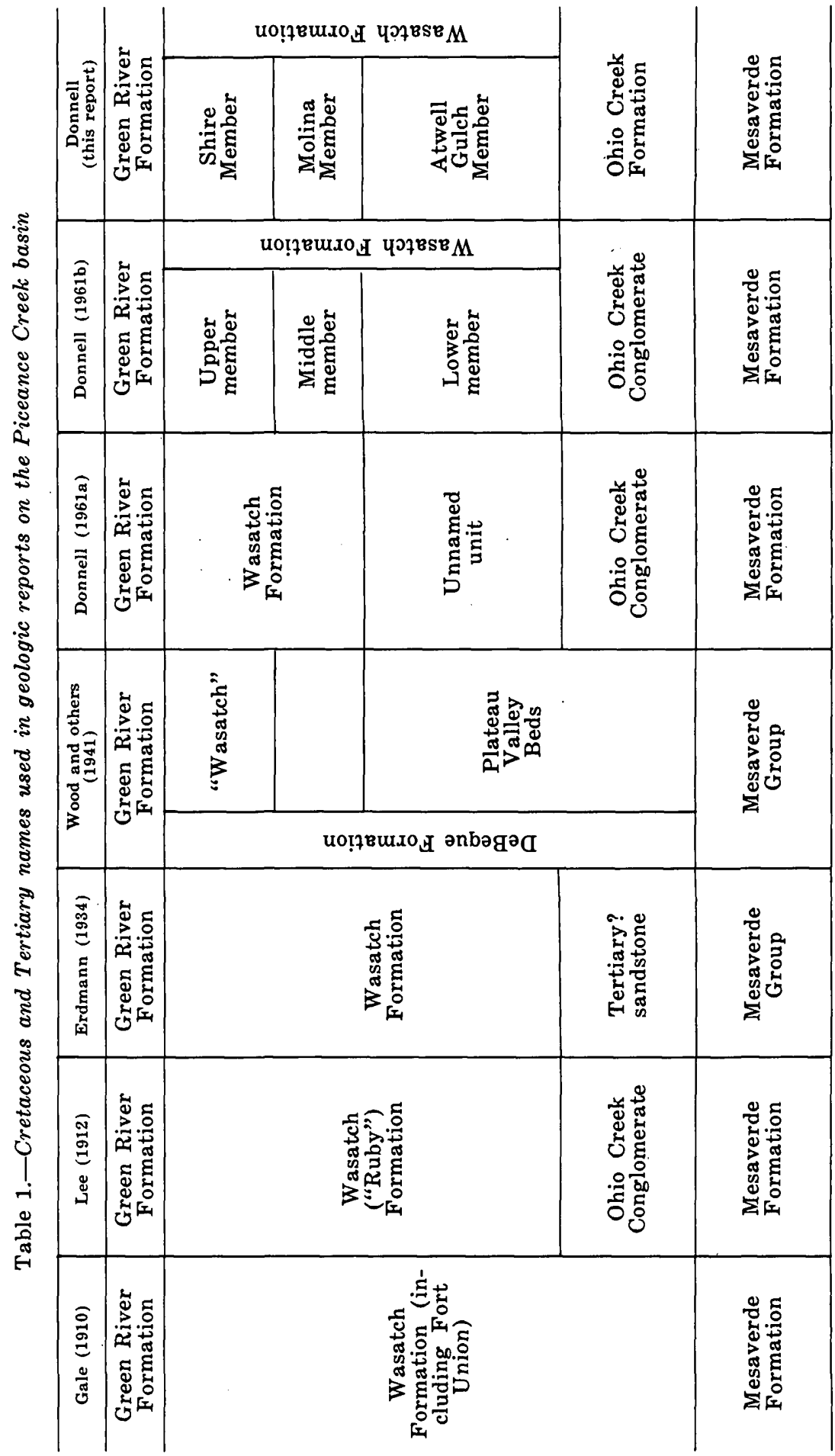


upper part of the Plateau Valley Beds of Patterson. In another report (Donnell, 1961b) the Wasatch was divided into three members, equivalent to the Atwell Gulch, Molina, and Shire Members, in the vicinity of DeBeque. These consisted of upper and lower dominantly varicolored claystone members separated by a thick ledge-forming sandstone member. The lower member is equated with that part of the Plateau Valley Beds which overlies the Ohio Creek Formation.

\section{STRATIGRAPHIC RELATIONS OF THE UPPER PALEOCENE AND LOWER' EOCENE ROCKS}

OHIO CREEK FORMATION

The Ohio Creek Formation in the Piceance Creek basin consists chiefly of a single massive sandstone or a series of massive sandstones that generally weather white and form a conspicuous band just above the ledge-forming brown sandstones of the uppermost beds of the Mesaverde Formation and below the dominantly shale and claystone slopes of the overlying Wasatch Formation. (See fig. 3.) In a few places, however, the sandstone of the Ohio Creek is dark red. The sandstones in the Ohio Creek Formation contain a distinctive suite of pebbles consisting principally of red and black chert, red and white quartzite, and white quartz, with minor amounts of limestone and granitic rock. The pebbles are erratically distributed through the sandstone and vary from a few small pebbles less than 1 inch in diameter that are scattered through a thick massive sandstone, as at the mouth of DeBeque Canyon, to beds containing abundant pebbles and cobbles as much as several inches in diameter. Because of varying lithology from place to place, the Ohio Creek is frequently difficult to recognize on electric logs from wells drilled for oil and gas. The Ohio Creek is exposed along the southern and eastern margin of the Piceance Creek basin; it is locally exposed in the Douglas Creek drainage and has been recognized in samples from some wells in the northcentral part of the Piceance Creek basin.

ATWELL GULCH MEMBER (NEW) OF THE WASATCH FORMATION

The Atwell Gulch Member of the Wasatch Formation is named from exposures along Atwell Gulch, the type locality, a tributary of Plateau Creek west of the town of Molina (section A, fig. 2). The section measured at the $\mathrm{N} 1 / 2$ sec. 26 and the $\mathrm{S} 1 / 2$ sec. 23 , T. 9 S., R. 97 W., is designated as a reference section. It is the lowermost member of the Wasatch Formation in this area. The member rests on the Ohio Creek Formation and underlies the basal dominantly sandstone unit of the middle member of the Wasatch Formation. It can definitely be traced on the surface and in the subsurface over an area of several hundred square 


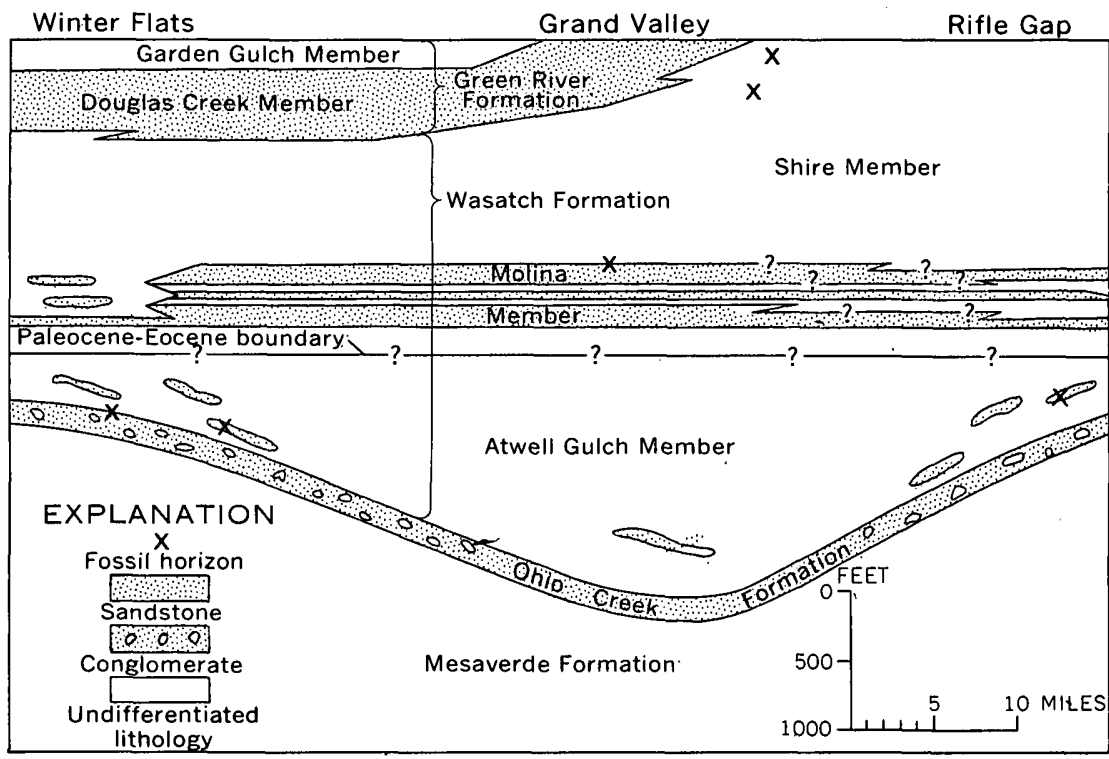

Figure 3.-Generalized stratigraphic relations of the Wasatch and adjacent formations in the southern part of the Piceance Creek basin. Contacts queried where uncertain.

miles in the general area of DeBeque, Grand Valley, Mesa, and Collbran. A similar unit, not as well defined, can be delineated along the Grand Hogback north and east of Rifle.

Lithologically the Atwell Gulch Member is the most variable part of the Wasatch Formation. In the vicinity of DeBeque Canyon it contains, in the lower part, a carbonaceous shale and lignite zone that is traceable over a 5-square-mile area. Northeast and east of DeBeque (fig. 4), where the lower part is not exposed, the upper part consists of gray claystone and siltstone approximately 200 feet thick overlain by 150 feet of lenticular brown sandstone, carbonaceous shale, and lignite beds. This is lithologically very similar to stratigraphically equivalent rocks along the Grand Hogback (fig. 5). South of DeBeque the lowest one-quarter of the member contains minor amounts of variegated claystone and numerous gray sandstone and siltstone lenses, some of which contain a suite of pebbles similar to that in the Ohio Creek Formation. The remainder of the member consists mostly of variegated claystone, minor amounts of lenticular sandstone, and a few thin fresh-water limestone beds. The Atwell Gulch Member ranges in thickness from about 700 feet on the outcrop along Atwell Gulch to approximately 1,850 feet in the subsurface south of Grand Valley. 


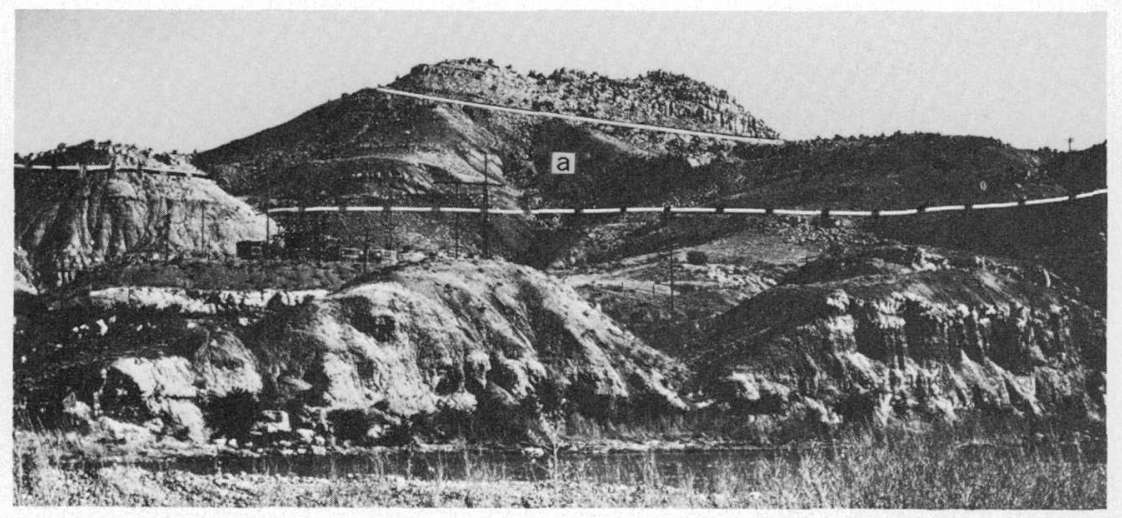

FIgURE 4.-Molina Member of the Wasatch Formation, capping hill east of DeBeque, underlain by incompletely exposed Atwell Gulch Member. Interval "a" contains dominantly brown shale, black carbonaceous shale, and thin lignite beds.

The Atwell Gulch Member is late Paleocene (Tiffanian provincial age) and possibly early Eocene in age. Paleocene mammalian fossils have been collected from several localities and several horizons in the lower 200 feet of the member in the area around and between DeBeque and Molina (Patterson, 1939; fig. 6). In addition, Roland W. Brown (Donnell, 1961a, p. 845) collected and identified Paleocene plant fossils from the carbonaceous zone near the base of the member at the east end of DeBeque Canyon. F. H. Knowlton (Gale, 1910, p. 79) identified Paleocene plants from a zone about 200 feet above the Ohio Creek Formation at Rifle Gap along the west side of the Grand Hogback, a few miles north and east of Rifle. No fossils have been reported from the beds in the interval between the top of the member and a horizon about 200 feet above the base of the member.

\section{MOLINA MEMBER (NEW) OF THE WASATCH FORMATION}

The Molina (middle) Member of the Wasatch Formation is named from good exposures on a prominent hill north of Plateau Creek about 1 mile west of Molina, the type locality. Three reference sections are designated B1, B2, and B3 (fig. 2). The basal boundary, a fairly sharp contact, is at the base of the lowest persistent arkosic sandstone that overlies the Atwell Gulch Member. The upper contact, a little less distinct, is at the top of the persistent sandstone sequence. Almost everywhere the upper sandstones are lenticular, and the contact varies in its stratigraphic position from place to place. 

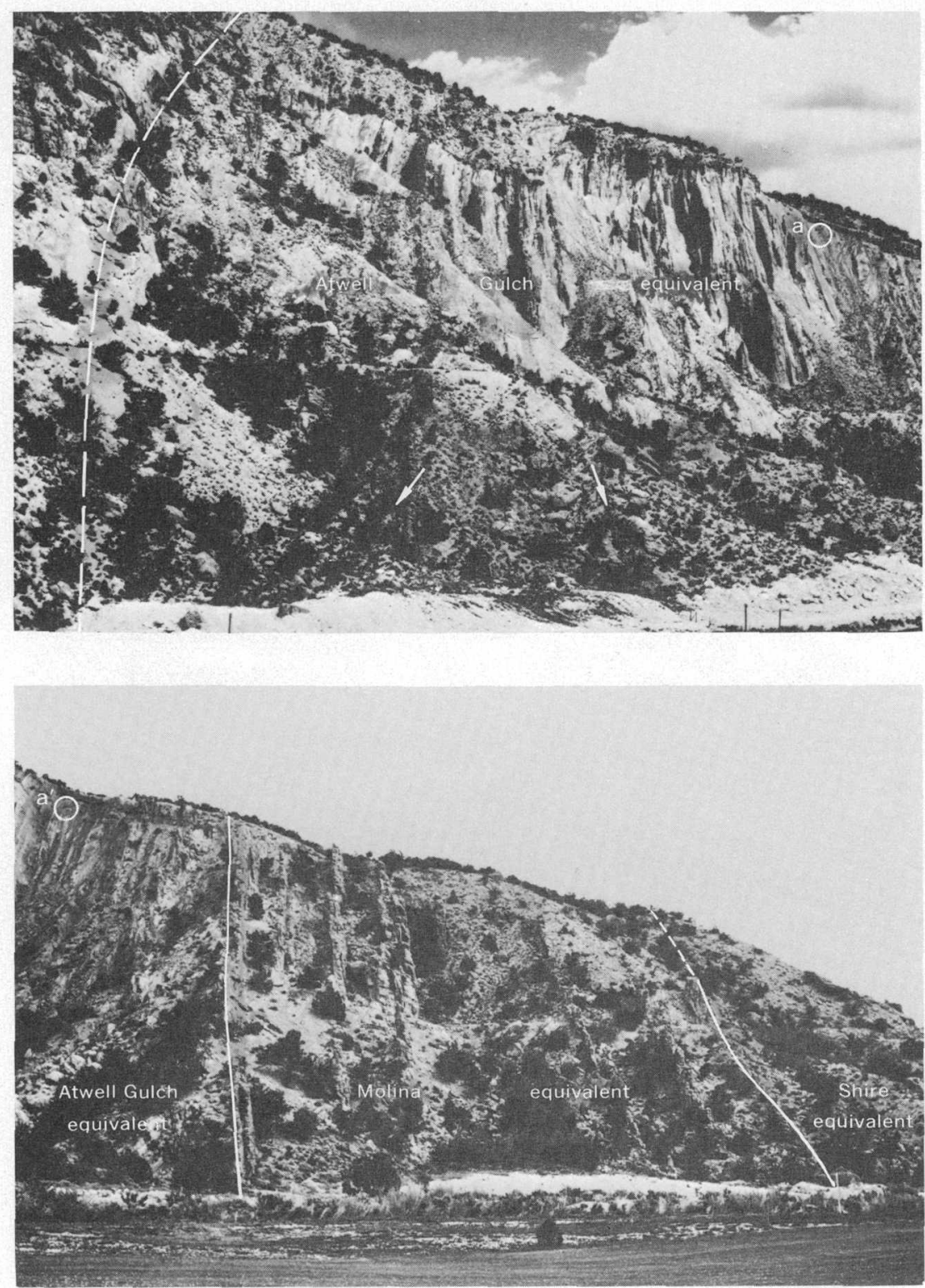

FIgURE 5.-Steeply dipping rocks at Rifle Gap. Upper, rocks of the Ohio Creek Formation (to left of dashed contact) and beds equivalent to the lower part of the Atwell Gulch Member at Rifle Gap. "a" is at position of " $a$ " in lower photograph. Arrows indicate plant localities. Lower, rocks equivalent to the Molina Member, the upper part of the Atwell Gulch Member, and the lower part of the Shire Member on the south side of Rifle Gap. 


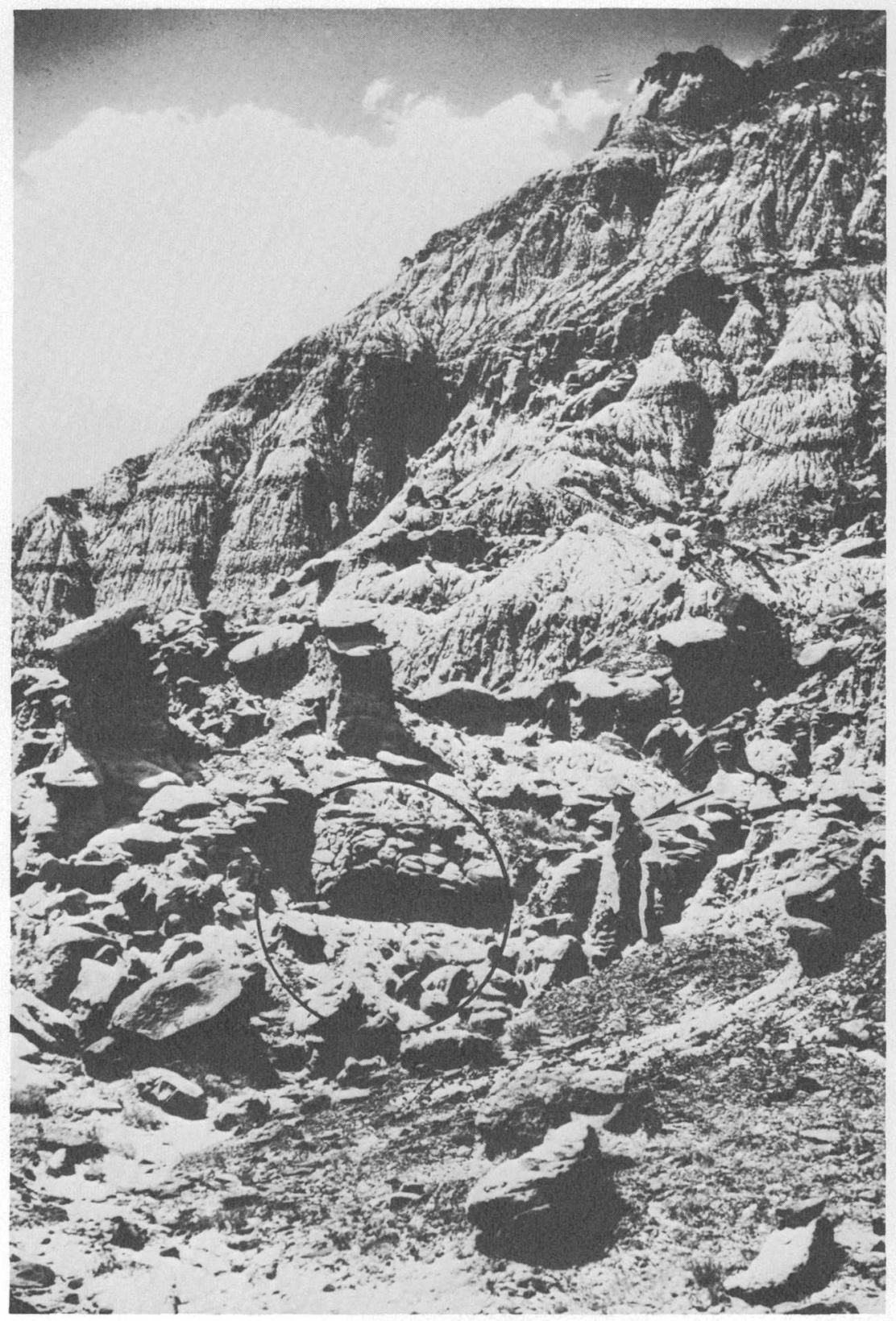

Figure 6.-Vertebrate quarry in Atwell Gulch Member (approximately 2,800 ft east of west line and $400 \mathrm{ft}$ south of north line, sec. 26 , T. 9 S., R. 97 W.). Site is about $200 \mathrm{ft}$ above Ohio Creek Formation. Quarry in circle; man (arrow) for scale. 
The Molina Member is exposed along 200 linear miles of outcrop in the vicinity of Mesa and DeBeque (fig. 4), and it underlies the western half of Grand and Battlement Mesa, an area of more than 350 square miles that extends as far eastward as Collbran and Grand Valley. At Rifle Gap (fig. 5, lower photograph), beds possibly equivalent to the Molina Member are about 400 feet thick and they lie about 700 feet above the base of the Wasatch Formation. North of here, intermittent exposures along the Grand Hogback indicate that the Molina equivalent is present, but it is not as easily recognized as at Rifle Gap.

A similar sandstone zone about 2,000 feet above the Ohio Creek Formation is exposed along Colorado State Highway 13 north of Rifle and is recognizable in some of the wells in the eastern part of the Piceance Creek basin. This zone is not directly traceable into the Molina west of Rifle, but it is possibly correlative.

Continuous thick-bedded brown arkosic ledge-forming sandstone characterizes the Molina Member. Locally, individual sandstone beds are red, green, or gray.. Minor amounts of variegated claystone form partings between the sandstone beds. In the outcrop, the proportion of claystone to sandstone increases westward where on the southwest side of Chalk Mountain and on Winter Flats (fig. 1) the sandstone beds are replaced by claystone and siltstone. The Molina Member is prominent east of the DeBeque cutoff road that connects U.S. Highway 6 and Colorado State Highway 65, and along Colorado State Highway 330 in the vicinity of Molina. In this area the sandstone is thicker bedded and coarser grained than elsewhere, and in places it is conglomeratic. The pebbles in the conglomerate are as large as several inches in diameter and are similar in composition to those in the Ohio Creek Formation.

The Molina Member ranges in thickness from a wedge edge in the vicinity of Chalk Mountain and Winter Flats to slightly more than 500 feet in the Mickelson 1 well (T. 11 S., R. 94 W.) and in the McCurry well (T. 9 S., R. 94 W.) (fig. 2). A unit that is the possible equivalent attains a thickness of more than 600 feet in the Carter and Carter 1 E. C. Hunter well (T. 6 S., R. 94 W.) (fig. 2); in this well, the sandstone beds are thin and separated by thick units of siltstone and variegated claystone. The basal sandstone in all three wells, as elsewhere in the surface and subsurface, appears to be the most persistent unit in the member.

No fossils have been reported from the Molina Member; however, Bryan Patterson (oral commun., 1965) reported Eocene vertebrates from the beds immediately overlying the member at the type locality. 
SHIRE MEMBER (NEW) OF THE WASATCH FORMATION

The Shire Member of the Wasatch is named for excellent exposures along the headwaters of Shire Gulch in the NE1/4 sec. 19, T. 9 S., R. 96 W., the type locality. The measured section at the SE $1 / 4$ sec. 13 , T. 9 S., R. 97 W., and the S1/2 sec. 18, T. 9 S., R. $96 \mathrm{~W}$., is designated as the reference section $\mathrm{C}$ in figure 2. The Shire is the upper member of the Wasatch Formation. Its base is at the top of the uppermost persistent sandstone in the Molina Member, and the top is at the base of the lowermost sandstone bed in the Douglas Creek Member of the Green River Formation.

The principal rock type in the Shire Member is claystone. The dominant colors are pastel shades of lavender, purple, and red. Some thick lenticular sandstone beds are elsewhere equivalent to the upper beds of the Molina Member. Above these lower thick sandstone beds are a few thin ( $1 \mathrm{ft}$ to several feet thick) lenticular gray sandstone and gray claystone beds. Along the south flank of Battlement Mesa the uppermost part of the member intertongues with the Douglas Creek Member of the Green River Formation. On the north flank of Grand Mesa and the south flank of Battlement Mesa east of Collbran the upper part of the Shire is characterized by resistant lenticular brown ledge-forming sandstone beds separated from one another and from the overlying Green River sedimentary rocks by red claystone. These sandstone beds form topographic benches. At places, such as Red Mountain, a prominent hill 2 miles southeast of Collbran (fig. 1), the red claystone of the Shire Member is equivalent to sandstone of the Douglas Creek Member. The Shire Member along the Grand Hogback also intertongues with the lower part of the Green River Formation. Two thin tongues of the Green River Formation are exposed over several square miles east of DeBeque on the lower slopes of Mount Logan. These tongues cap minor benches in the upper 400 feet of the Shire Member and consist mainly of resistant brown calcareous sandstone and subordinately of a light-brown flaky shale. Fragments of a brown ostracodal limestone less than 1 inch thick are scattered on the surface of the capping sandstone at many places.

The Shire Member underlies an area equal to that underlain by the Molina Member. The Shire is about 900 feet thick in the type locality, thins to about 600 feet in the subsurface underlying Grand Mesa, and thickens to more than 1,800 feet in the subsurface in wells south of Grand Valley on the north flank of Battlement Mesa. The probable stratigraphic equivalent of the Shire Member along the Grand Hogback attains an exposed thickness in excess of 4,000 feet. 
As mentioned above, early Eocene mammal remains have been found in the lower part of the Shire Member at the type locality of the Molina Member. Wood (1962) described collections of the middle early Eocene and late early Eocene rodents from localities near the upper part of the Shire Member north of the Colorado River and about midway between Rifle and Grand Valley (fig. 3).

\section{SUMMARY OF NEW TERMS AND AGES}

Atwell Gulch Member.-The Atwell Gulch Member is the lower member of the Wasatch Formation. It consists mostly of purple, lavender, red, and gray claystone and minor amounts of gray and brown lenticular sandstone and siltstone near the base. Paleocene vertebrates and leaves have been collected from the basal 200 feet of the Atwell Gulch Member; no fossils have been reported from the rest of the member.

Molina Member.-The Molina Member is the middle member of the Wasatch Formation. It consists primarily of massive brown, gray, red, or green persistent sandstone beds with minor amounts of variegated claystone. No fossils have been reported from this member, but its probable age is early Eocene.

Shire Member.-The Shire Member is the upper member of the Wasatch Formation. It consists primarily of purple, lavender, and red claystones and minor amounts of gray claystone, but contains some poorly bedded lenticular brown sandstone near the base of the member. In places, the upper part of the Shire Member intertongues with and is equivalent to the Douglas Creek Member of the Green River Formation. Early Eocene mammals have been reported from the lower part of the member near Molina and middle early and late early Eocene rodents have been reported from the upper part of the member west of Rifle.

\section{REFERENCE SECTIONS OF THE ATWELL GULCH, MOLINA, AND SHIRE MEMBERS OF THE WASATCH FORMATION}

[No sections measured at type localities]

A. Atwell Gulch Member of the Wasatch Formation, $N^{1 / 2}$ sec. 26 and $S^{1 / 2}$ sec. 23, T. 9 S., R. $97 W$.

Wasatch Formation, Atwell Gulch Member:

Thickness

Claystone, green (feet)

Sandstone and claystone, olive green 24.2

Sandstone, gray, medim-grained, massive, lenticular …................ 6.0

Claystone, lavender, medium-gray .................................................. 50.7

Sandstone, brown, limonitic ....................................................... 10.0

Claystone .................................................................................... 40.6

Sandstone, brown, medium-grained, massive, lenticular ................. 12.0

Claystone, purple; some lavender .................................................. 53.2

Sandstone, brown, massive, lenticular ......................................... $\quad 8.0$ 
A. Atwell Gulch Member of the Wasatch Formation, $N 1 / 2$ sec. 26 and $S 1 / 2$ sec. 23, T. 9 S., R. 97 W.-Continued

Wasatch Formation, Atwell Gulch Member-Continued

Claystone, lavender and purple; some tan at base ......................... 49.3

Sandstone, gray ........................................................................ 11:5

Claystone, lavender; some gray and brown ...................................... 25.1

Sandstone, gray, medium-grained .................................................... 11.4

Claystone; lavender at top and base, gray in middle ..................... 31.6

Sandstone, gray, fine-grained ..................................................... $\quad 3.0$

Claystone; gray at top, purple and lavender at base ..................... 10.0

Sandstone, gray, very fine grained to fine-grained;

calcareous cement; lenticular .................................................... 3.5

Claystone, gray, purple, lavender; partially covered ...................... 81.2

Sandstone, brown, fine-grained to medium-grained;

forms prominent ledge ............................................................. 10.0

Mudstone, brown .......................................................................... 2.2

Limestone, gray ................................................................... 1.0

Sandstone, tan, fine-grained to medium-grained; quartz and feldspar; well consolidated

Claystone, gray, with $2 \mathrm{ft}$ of brown siltstone;

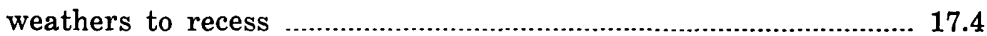

Covered; probably claystone ......................................................... 17.4

Sandstone, brown, coarse-grained; red quartz grains and feldspar; forms prominent ledge

Sandstone, brown, fine-grained, and gray claystone; unit forms recess

Covered slope; probably contains fine-grained brown sandstone and gray mudstone or claystone

Total Atwell Gulch Member of Wasatch Formation ................545.9

Ohio Creek Formation (incomplete) :

Sandstone, brown, coarse-grained; quartz; poorly consolidated; forms slope

Sandstone, light-tan, coarse-grained; quartz; contains some quartz and chert pebbles

Conglomerate; well-rounded chert and quartz pebbles as large as $3.5 \mathrm{in.}$ by $2.5 \mathrm{in}$.; forms recess between underlying and overlying sandstones

Sandstone, white to gray to light-tan, coarse-grained to very coarse grained, poorly cemented; weathers to a slope

Total Ohio Creek Formation measured $95.6+$

B1. Molina Member of the Wasatch Formation, N1/2 sec. 24, T. 9 S., R. 97 W.

Wasatch Formation, Molina Member:

Sandstone, gray, fine-grained to medium-grained, massive ........... 8.2

Claystone, gray and lavender; forms slope .................................... 23.0

Sandstone, gray, medium-grained, massive; quartz sand;

6-ft interval covered $10 \mathrm{ft}$ below the top

Covered slope; probably underlain by poorly consolidated sandstone

Sandstone, brown, medium-grained to coarse-grained; quartz sand; forms prominent ledge 
B1. Molina Member of the Wasatch Formation, N1/2 sec. 24, T. 9 S., R. 97 W.-Continued

Wasatch Formation, Molina Member-Continued

Covered slope

Sandstone, gray, medium-grained, massive; forms

prominent ledge

Covered slope; some claystone and green sand

Sandstone, gray, medium-grained, massive

Sandstone, green

Sandstone, gray, coarse-grained, pure quartz, poorly cemented ...

Covered slope; probably contains green claystone and green sandstone

Sandstone, dark-gray to light-tan, fine-grained, massive; recess at base

Sandstone, gray, medium-grained, massive; base of prominent ledge

Claystone, lavender to gray

Sandstone, gray, medium-grained 22.0

Sandstone, olive-green

Sandstone, gray, coarse-grained, massive; basal part contains pebbles

Covered; claystone in upper $6 \mathrm{ft}$

Sandstone, brown, medium-grained, massive, poorly cemented, slightly calcareous; $1 / 4$-in. to $1 / 2$-in. quartz and chert pebbles at base; capped with gray, fine-grained calcareous sandstone .... 23.2

Covered; some claystone

Sandstone, gray, fine-grained to medium-grained, massive, calcareous

Sandstone, brown, medium-grained to coarse-grained, massive, poorly cemented; some gray sandstone at top

Covered; forms slope

Sandstone, gray, fine-grained, massive

Claystone, lavender with some gray

Sandstone, tan to brown, medium-grained, persistent, well-cemented

Total Molina Member of Wasatch Formation.

B2. Molina Member of the Wasatch Formation, $S 1 / 2$ sec. $31, T .9$ S., R. 95 W., and $N 1 / 2$ sec. $6, T .10$ S., R. $95 \mathrm{~W}$.

Wasatch Formation, Molina Member:

Sandstone, light-gray, medium-grained; forms ledge

Covered slope; probably underlain by siltstone or claystone 20.3

Sandstone, light-gray, fine-grained to medium-grained, poorly bedded

Siltstone, gray; forms recess under overlying sandstone ................ 3.4

Covered; probably siltstone or claystone............................................. 11.6

Sandstone, fine-grained, thin-bedded to medium-bedded ................. 7.7

Covered interval

Sandstone, gray, medium-grained, crudely crossbedded;

forms a very prominent ledge

Poorly exposed; scattered exposures of dark-green siltstone and dark-gray claystone; forms bench 
B2. Molina Member of the Wasatch Formation, $S 1 / 2$ sec. $31, T .9$ S., R. 95 W., and $N^{1 / 2}$ sec. $6, T .10 \mathrm{~S}$., R. $95 \mathrm{~W}$.-Continued

Wasatch Formation, Molina Member-Continued

Thickness (feet)

Sandstone, light-gray, fine-grained to medium-grained; forms prominent ledge

Poorly exposed; scattered exposures show green and gray claystone and siltstone

Sandstone, gray, medium-grained; near base are $1 / 2$-in. pebbles of chert, quartz, and quartzite

Siltstone, greenish-gray; forms bench or recess under overlying sandstone

Sandstone, light-gray, medium-grained to coarse-grained

Conglomerate, contains pebbles of quartz, quartzite, and chert as large as $2 \frac{1}{2} \mathrm{in}$. in diameter; several feet of relief on basal contact

Sandstone, light-gray, coarse-grained, massive, feldspathic; contains scattered pebbles of quartz, quartzite, and chert

Poorly exposed; scattered exposures show varicolored claystones.... 11.6

Sandstone, light-gray, medium-grained to coarse-grained, massive, arkosic; irregular basal contact, lowermost few inches contains white and brown quartz and white and brown quartzite pebbles as long as $3 / 4$ in.

Sandstone, light-gray, very fine grained; forms basal part of prominent ledge

Siltstone, dark-gray; light-gray claystone; forms recess

Total Molina Member of Wasatch Formation

B3. Molina Member of the Wasatch Formation, $N W^{1 / 4}$ sec. 4, T. 10 S., R. 96 W.

Wasatch Formation, Molina Member:

Sandstone, light-brown, poorly sorted, feldspathic

Covered slope; probably claystone or shale

Sandstone; upper one-third gray, medium grained, massive, poorly sorted, feldspathic; middle one-third brown, medium grained, thin bedded, and poorly sorted; basal one-third brown, medium grained to coarse grained, massive, poorly sorted

Covered slope; scattered exposures indicate interval is mainly green and gray claystone; basal part probably underlain by light-gray siltstone; $5 \mathrm{ft}$ of relief on contact between this and overlying unit

Sandstone, gray, fine-grained to very fine grained, calcareous; interbedded with claystone; lowest $2 \mathrm{ft}$ contains quartz, chert, and quartzite pebbles in a claystone matrix

Covered slope; upper part is probably underlain by light-green silty claystone; lower part probably underlain by dark-green siltstone or very fine grained sandstone

Sandstone; light greenish gray and fine grained to very fine grained at top; light brown and medium grained to fine grained in middle; reddish brown and medium grained at base.... 23.2

Slope; probably underlain by claystone or shale; in the middle is $3 \mathrm{ft}$ of green very fine grained sandstone 
B3. Molina Member of the Wasatch Formation, NW1/4 sec. 4, T. 10 S., R. 96 W.-Continued

Wasatch Formation, Molina Member-Continued

Sandstone, gray to brown; basal $4 \mathrm{ft}$ is green conglomeratic sandstone containing pebbles of tan, red, and black chert, brown quartzite, and white quartz; remainder of unit contains a few pebbles

Covered slope

Slope; probably underlain by green siltstone and green and red silty claystone

Sandstone, reddish-brown with green mottling (green in basal part), fine-grained to medium-grained; thin zones contain small pebbles of red and brown chert

Claystone, greenish-gray; forms a flat bench

Sandstone, gray, fine-grained, feldspathic; forms ledge; contains inclusions of green sandstone and in upper one-third a few quartz pebbles

Sandstone, olive-green, fine-grained to medium-grained, slightly calcareous; contains a few brown quartzite and black chert pebbles

Sandstone, light-gray, fine-grained, massive, slightly calcareous, ledge-forming; contains inclusions of light-green and darkgreen siltstone

Covered slope; probably underlain by light-green claystone and fine-grained dark-green sandstone

Sandstone, light-green, fine-grained to medium-grained, massive, feldspathic, calcareous; contains gray clay pebbles at base; forms prominent ledge

Total Molina Member of Wasatch Formation $\overline{332.4}$

C. Shire Member of the Wasatch Formation, SE1/4 sec. 13, T. 9 S., R. 97 W., and $S 1 / 2$ sec. $18, T .9$ S., R. $96 \mathrm{~W}$.

Wasatch Formation, Shire Member:

Claystone, red, brown, and lavender 46.4

Claystone, light-purple

Claystone, red, lavender, and brown, alternating 64.8

Limestone and sandstone; thin-bedded calcareous sandstone at top; gray medium-grained sandstone in middle; gray limestone at base

Claystone, lavender and purple

Sandstone, gray; or limy sandstone; contains thin clay partings.... 11.4

Claystone, mostly red and brown; some lenticular sandstones ........ 30.0

Sandstone, gray, medium-grained, very calcareous ........................... 1.5

Claystone, purple; contains a few thin sandstones ........................... 16.4

Sandstone, gray, medium-grained, slightly calcareous ................... 1.5

Claystone, purple ....................................................................... 28.5

Sandstone, gray, very fine grained, calcareous ............................... 1.5

Claystone, brown, some purple .................................................. 98.6

Claystone, light-purple, some gray and brown ............................... 63.8

Claystone, red, some lavender and purple ....................................... 25.2

Claystone, gray and brown ........................................................... 29.0

Claystone, light-purple ............................................................... 11.6 
C. Shire Member of the Wasatch Formation, SE1/4 sec. 13, T. 9 S., R. 97 W., and $S 1 / 2$ sec. $18, T .9 S ., R .96 \mathrm{~W}$.-Continued Thickness

Wasatch Formation, Shire Member-Continued

Claystone, brown and lavender

Claystone, gray and light-purple

Claystone, lavender and purple; brown zone in middle

Claystone, gray; light-purple at base

Claystone, purple

Claystone, lavender

Claystone; mostly lavender with some purple.

Claystone; mostly brown with some lavender and purple ............... 52.2

Sandstone, calcareous, or sandy limestone ................................... $\quad 1.0$

Claystone; mostly lavender with some purple and some gray ........ 58.0

Sandstone, gray, fine-grained to medium-grained, thin-bedded ........ $\quad 1.0$

Claystone, purple; gray near the top .............................................. 29.0

Covered slope; scattered exposures indicate slope underlain

by lavender claystone ................................................................ 40.6

Sandstone, calcareous, or sandy limestone ...................................... 5.6

Covered; probably underlain by claystone ....................................... 16.0

Total Shire Member of Wasatch Formation ............................ $\overline{951.4}$

\section{REFERENCES CITED}

Donnell, J. R., 1961a, Tertiary geology and oil-shale resources of the Piceance Creek basin between the Colorado and White Rivers, northwestern Colorado: U.S. Geol. Survey Bull. 1082-L, p. 835-891.

1961b, Tripartition of the Wasatch Formation near DeBeque in northwestern Colorado, in Short papers in the geologic and hydrologic sciences: U.S. Geol. Survey Prof. Paper 424-B, p. B147-B148.

Erdmann, C. E., 1934, The Book Cliffs coal field in Garfield and Mesa Counties, Colorado: U.S. Geol. Survey Bull. 851, 150 p. [1935].

Gale, H. S., 1910, Coal fields of northwestern Colorado and northeastern Utah: U.S. Geol. Survey Bull. 415, 265 p.

Lee, W. T., 1912, Coal fields of Grand Mesa and the West Elk Mountains, Colorado: U.S. Geol. Survey Bull. 510, 237 p.

Patterson, Bryan, 1933, A new species of the amblypod Titanoides from Western Colorado: Am. Jour. Sci., 5th ser., v. 25, no. 149, p. 415-425.

1934, A contribution to the osteology of Titanoides and the relationships of the Amblypoda: Am. Philos. Soc. Proc., v. 73, no. 2, p. 71-101.

1936, Mounted skeleton of Titanoides, with notes on the associated fauna [abs.]: Geol. Soc. America Proc. 1935, p. 397-398.

1939, New Pantodonta and Dinocerata from the upper Paleocene of western Colorado: Field Mus. Nat. History Pub. 1441, Geol. Ser., v. 6, no. 24 , p. $351-384$.

Wood, A. E., 1962, The early Tertiary rodents of the family Paramyidae: Am. Philos. Soc. Trans., 1962, v. 52, pt. 1, 261 p.

Wood, H. E., chm., and others, 1941, Nomenclature and correlation of the North American continental Tertiary: Geol. Soc. America Bull., v. 52, no. 1, p. 1-48. 